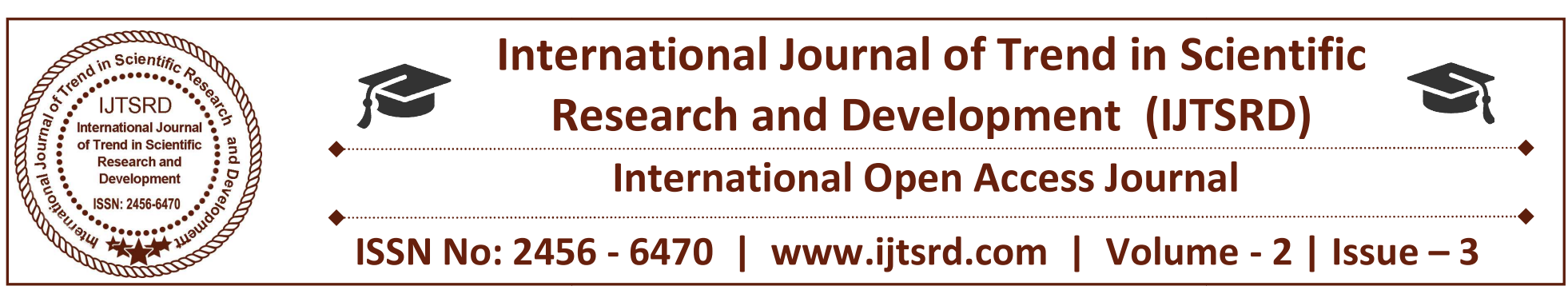

\title{
Impact of Integrated Handloom Cluster Development Scheme (IHCDS) on Social Conditions of Weavers: The Opinion of Member Weavers in Andhra Pradesh, India
}

\author{
Prof. K. Rama Mohana Rao \\ Professor, Department of Commerce and \\ Management Studies, Andhra University, \\ Visakhapatnam, India
}

\author{
Kakumanu Kiran Kumar \\ Research Scholar, Department of Commerce and \\ Management Studies, Andhra University, \\ Visakhapatnam, India
}

\begin{abstract}
Handlooms form the maximum employment generating, labour intensive and export oriented industry especially in rural and semi-urban areas of India. The handloom sector carries a very rich heritage coming down over the centuries of vibrant culture that of Indus valley civilization. Handloom sector is a prime and emergent economic necessity since it sustains the economy of predominantly reveal based nation. It provides direct and indirect employment to millions of artisans spread all over the nation. Indian Handloom sector is an age old and major sector of cottage industries. This traditional rural and largest semi urban sector has widely spread all over the country. Today, the handloom sector in India presents multifaceted problems which are more complicated in view of its social importance. Handloom weaving gave to power weaving as surviving only in a few countries, of which India is the most imperative and predominant one. The main reason for the existing of handloom in India is the social conditions of our country and the industry's high employment potential. This paper aims to study the impact of various social conditions of the weavers working in the handloom sector.
\end{abstract}

Keywords: Cluster, Development, Handlooms, Social conditions, Weavers

\section{INTRODUCTION}

One of the largest family-based traditional industries in India is handloom sector. The Handloom industrial sector is a pre-market, pre-capitalist industry that produces fabric using hand-operated looms (Mukund and Sundari, 2001). Handloom sector is highly labour intensive industry with a low capital investment. It is also a low energy sector with no adverse impact on the environment as weaving is totally a pollution free activity. The strength of handloom lies in introducing innovative designs, which cannot be replicated by the power loom sector.

The Handloom sector plays a very significant role in the country's economy. As per Handloom census (2009-10) shown in Table-1 there are 23.77 lakh handlooms in India and 43.32 lakh handloom weavers and allied workers in India. The handloom work force is predominantly female, constituting 77.90 per cent of the total work force. The man days worked per annum per weaver were 234 days and the share of full time weavers in the total was 64 per cent. The share of weaver households reporting more than 60 per cent income from handlooms and related activities was 35 per cent. The idle looms, however, was only 4 per cent. The findings of the census indicate that there are some improvements in the status of handloom industry in the country. 
Table-1. Handlooms in India as per 2010 Census

\begin{tabular}{|l|l|}
\hline Details & $\begin{array}{l}\text { Handloom } \\
\text { Census } \\
2010\end{array}$ \\
\hline $\begin{array}{l}\text { No. of weavers and allied } \\
\text { workers }\end{array}$ & 43.32 lakh \\
\hline No. of looms & 23.77 lakh \\
\hline Women weavers (\%) & 77.90 \\
\hline $\begin{array}{l}\text { Total man-days worked by } \\
\text { weaver households (lakh) } \\
\text { during census }\end{array}$ & 5,313 \\
\hline $\begin{array}{l}\text { Man-days worked per weaver } \\
\text { household during census year }\end{array}$ & 234 \\
\hline $\begin{array}{l}\text { Share of full-time weavers to } \\
\text { total weavers }\end{array}$ & $64 \%$ \\
\hline $\begin{array}{l}\text { Share of weaver households } \\
\text { reporting more than 60 per } \\
\text { cent income from handlooms } \\
\text { and related activities }\end{array}$ & $35 \%$ \\
\hline Share of idle looms & $4 \%$ \\
\hline
\end{tabular}

Source: NCAER, Handloom Census 2009-10.Ministry of Textiles and Handlooms, Government of India

A handloom forms a part of the heritage of India and represents the richness and diversity of our country and the artistry of the weavers (Fayaz Ahmad and Hussain, 2013). The popular belief is that the handloom industry has survived only because of government support (Tasneem Shazli and Abdul Munir, 2014). However, an alternative viewpoint suggests that the industry endured because of its ability to adapt to the challenging needs of the textile markets of India by providing quality goods with skillful designs (Mukund and Sundari, 2001; Bharatan, 1988). A look at the handloom industry over the past years reveals that the changes in production technology are few but the changes in the market are substantial. While handlooms has been losing the low end market to the power looms, it has been gaining new ground in the high and mid-range markets with its creation of new niches.

Human factor is the most vital factor for taking initiatives for the development of handloom industry in India. The social profile of the industry gives an understanding on the status of the human resources of the industry and helps in designing policies and programmes for the promotion of social and financial inclusion of the deprived sections of the society. The sector wise composition of handloom sector in India is an indication of the share of handloom industry in the textile industry of the country. As can be seen from Figure-1, power loom sector takes the major share with 59 per cent stake in the textile industry in India. The share of handloom sector is 11 per cent and the textile mill sector contributes only 4 per cent.

\section{Figure-1. Sector-wise composition of textile industry in India}

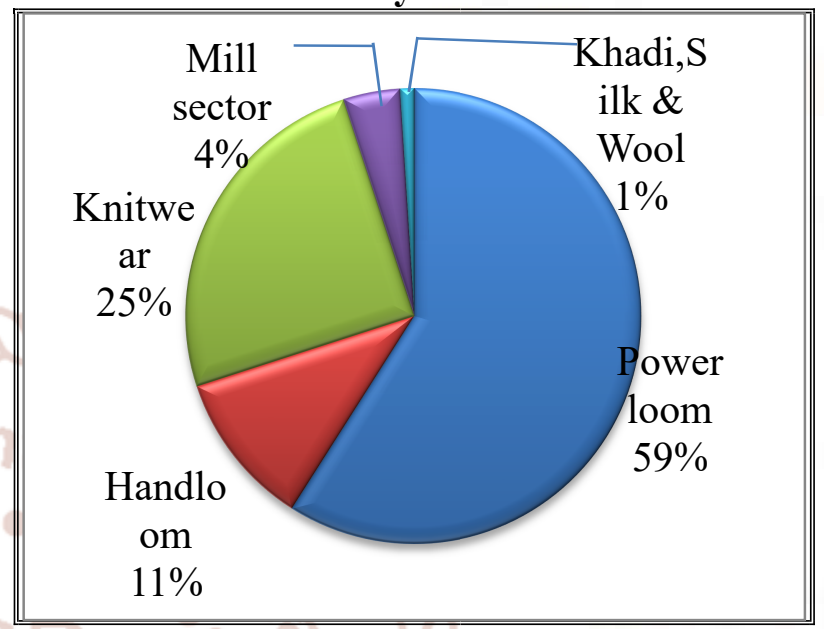

Source: Ministry of Textiles, GOI

The data presented in Table- 2 reveals the distribution of handloom households by social groups in rural and urban parts of the country. It can be observed that the major group of handloom weaving households belongs to Other Backward Classes (OBC). Out of the total, 40.9 per cent weaver households are from Other Backward Classes. Schedule Tribes are the $2^{\text {nd }}$ largest group and their share in the total handloom households in India is 22.1 per cent. About 10 per cent of the handloom households belong to Schedule Castes (SC). The other social groups constitute 27.2 per cent among the handloom households. Out of the total 86.99 per cent of handloom households are in rural areas and 13.01 per cent of handloom households are in urban areas. It can be inferred from the data that the handloom industry is largely located in rural areas and about 73 per cent of handloom households belong to socially and economically deprived sections of the society. 
International Journal of Trend in Scientific Research and Development (IJTSRD) ISSN: 2456-6470

Table 2: Distribution Handloom Households by Social Groups

\begin{tabular}{|l|l|l|l|}
\hline \multirow{2}{*}{$\begin{array}{l}\text { Social } \\
\text { groups }\end{array}$} & \multicolumn{3}{|l|}{ Number of households } \\
\cline { 2 - 4 } $\begin{array}{l}\text { Scheduled } \\
\text { Castes } \\
\text { (SCs) }\end{array}$ & $\begin{array}{l}236,188 \\
(8.49)\end{array}$ & $\begin{array}{l}36,868 \\
(1.32)\end{array}$ & $\begin{array}{l}273,056 \\
(9.81)\end{array}$ \\
\hline $\begin{array}{l}\text { Scheduled } \\
\text { Tribes } \\
\text { (STs) }\end{array}$ & $\begin{array}{l}598,574 \\
(21.50)\end{array}$ & $\begin{array}{l}16,703 \\
(0.61)\end{array}$ & $\begin{array}{l}615,277 \\
(22.11)\end{array}$ \\
\hline $\begin{array}{l}\text { Other } \\
\text { backward } \\
\text { Castes } \\
\text { (OBCs) }\end{array}$ & $\begin{array}{l}928,613 \\
(33.37)\end{array}$ & $\begin{array}{l}210,332 \\
(7.55)\end{array}$ & $\begin{array}{l}1,138,945 \\
(40.92)\end{array}$ \\
\hline Others & $\begin{array}{l}657,742 \\
(23.63)\end{array}$ & $\begin{array}{l}98,251 \\
(3.53)\end{array}$ & $\begin{array}{l}755,993 \\
(27.16)\end{array}$ \\
\hline Total & $\begin{array}{l}2,421,117 \\
(86.99)\end{array}$ & $\begin{array}{l}362,154 \\
(13.01)\end{array}$ & $\begin{array}{l}2,783,271 \\
(100.0)\end{array}$ \\
\hline
\end{tabular}

Source: NCAER, Handloom Census 2009-10.Ministry of Textiles and Handlooms, Government of India

\section{Integrated Handloom Cluster Development Scheme (IHCDS) in Andhra Pradesh}

Several schemes are being implemented for SocioEconomic Development of Handloom Weavers in Andhra Pradesh both through 100 per cent State and Central Government Schemes and matching schemes of the Central Government with State matching share as per the budget provisions. The Government of Andhra Pradesh also implemented the Centre initiated Integrated Handloom Cluster Development Scheme (IHDS) in 2007-08 with the following specific objectives.

- Focus on formation of Handloom Weavers Group as a visible entity.

- Develop the Handloom Weavers Groups to become self-sustainable.

- Inclusive approach to cover weavers both Cooperative and Outside Co-operative Fold.

- Skill Up-gradation of Handloom Weavers/ Workers to produce diversified products with improved quality to meet the market requirements.

In addition to the Central Government Schemes, the State Government also introduced some schemes for the development of socio economic conditions of the weavers and also the industry as a whole. The following are some of the schemes of the State Government such as: Interest Subsidy, Old Age Pensions to Weavers, State Government Loan
Weavers Scheme, Indiramma Housing Programme, Payment of Ex-Gratia to the Families of Suicidal Weavers, Establishment of Samishti Handloom Sales Emporia, Netha Bazaars, Scheme for Training and Infrastructural support to Handloom Sector, and Subsidy on Purchase Hank Yarn, Dyes \& Chemicals from NHDC and APCO.

\section{Review of Literature}

The study provides an extensive review of available literature in the area of handloom weaver's social conditions thorough understanding of the conceptual constructs and empirical research. Rao (1979) pointed out that the employment opportunities are declining in handloom industry. The weavers were trying to change their profession and taking up alternative jobs. According to the researcher, inadequate financial support from government, the weavers are facing the problem of hike in raw material cost, scarcity of necessary inputs, lack of proper production, marketing and financial facilities. Mahapatro (1986) the study revealed that the major evil in the handloom industry is master weavers. He pointed out that the master weavers have become exploiters of the poor weavers. However, the growth of the co-operative sector might lead to automatic shrinkage and ultimate extinction of the master weaver system. Ramamohana Rao (1990) study on 'Development of Handloom Industry' has focused on the socio-economic profile of the weavers in handloom industry in Andhra Pradesh. He presented an overall view of the performance of primary weavers' co-operative societies.

Lakshmi Narasaiah and Krishna (1999) studied the crisis in handloom industry. The study found that handloom industry has been facing the problem of improper financial facilities and irregular supply of yarn. As a result the raw material price increases every year and the cost of the handloom cloth have increased than the power loom Cloth. Gurumoorthy and Rengachary (2003) found that the main problems are shortage of input, poor working capital, pricing of handloom products, accumulation of huge stock and marketing of handloom products. Lakshmi Narasaiah (2004) stated that the problem of illiteracy in weaver's community is unchecked status. He opined the need to arrange special schools for weavers community with technical training related to the weaving. Savita (2006) has also explained that in weaving customer dreams' the success story of fabindia, a company for export on retail marketing of handlooms. She stated 
that fabindia's achievement as a major player in retail handloom sector in India is due to the fact the company have believed in good business practices and never compromised on best quality. The handloom industry, if managed well provides wealth and propensity to rural India. This is achieved because they understand how to invest in social and natural capital over a long period with a concurrent ability to manage the process.

Mahendra et al. (2008) studied the problems and prospects of the handloom sector in Andhra Pradesh. The master weavers, middle men and independent weavers are examined in their study with support of field work. They analyzed the threat of power loom and its competition on handloom weaving and concluded the power loom industry development is suppressing the handloom industry. Ramachandrappa (2009) tells about the handloom clusters patronages by KHDC (Karnataka Handloom Development Corporation). Different activities are conducted by KHDC. Almost all the weavers depend on job work. The weavers get raw materials from co- operative societies and produce for the societies. Weavers are under the master weavers of khadi board. KHDC and khadi board sells through outlets and directly to different government institutions where as small scale weavers sell their products directly to the customers. Merima Ali (2010) studied the handloom industry in four regions of Ethiopia. The findings of this study revealed the importance of cluster- based industrial activities as a reciprocal method of scattering indoctrination when local conditions do not allow easy access to credit. Specialization and division of labour minimize the barriers of minimizing the initial capital required to start a business of handloom sector in the four regions of Ethiopia. This effect is found to be notably larger for micro enterprises investing in districts with higher grades of capital market inefficiency, pointing out the importance of clustering as an organizational response to a confined credit environment. Arif Anjum and Thakor (2011) analyzed the functioning and the problems of power loom industry and stated that the Indian textile industry has an awesome existence in the Indian economy. It is second largest employer after agriculture in India. It is one of the largest in the world with massive raw material and textiles manufacturing base. Indirect employment including the manpower engaged in agricultural based raw-material production like cotton and related trade and handling could be stated to be around another 60 million. The Indian textile industry has their main segments as mill sector, handloom sector and decentralized power loom sector.

Sabeenian et al. (2012) stated that detection of defects on finished fabrics and their classification based on their appearance plays a vital role in inspection of both hand- woven and machine woven fabrics. The defect detection process is carried out by making use of the manual effort, during which some of fabric defects are very small and undistinguishable and can be identified only by monitoring the variation in the intensity falling on the fabric. Their study focuses on developing algorithms to check if a given fabric contains any one of the defects listed out in and is so what kind of defect and location of the defect within the analyzed area. Anant kamath and Robin Cowan (2012) revealed that when agents use informal interaction to exchange knowledge, their production relations develops as emergent properties of their social relations and exhibit homophile. The Saliyar community cluster in India is an archetype of this. Community and family sprit have assisted and given its own shape to the technology trajectory of handloom in most of India. But in the case of the saliyars, there has been a disharmony. They indicated that this does not question whether or not community social capital and technological progress share a healthy relation, but shows that there are limits beyond which the detriments of community social capital and rigidities associated with inherited networks set in, hindering knowledge diffusion and technological advancement. Tawheed et al. (2013) have analyzed the socio economic profile of silk weavers of Srinagar city. The study reveals that the situation of the weavers is worrying as they are feeble due to illiteracy, financial constraints, health problems, meager remuneration and poor Governmental support. Premsundar and Kannan (2013) stated that women's empowerment has become a growing concern both at the national and international levels on the subjugated, disadvantaged and status of women in the society. In India, this concern i.e. women's empowerment has to be focused mainly in non formal sectors, where the women's work force is predominant. One among them is handloom sector. Handloom is one of the largest economic activities, after agriculture, providing direct and indirect employment as well as being predominately a non-farm activity. Rubyjain and Rachana (2013) have made a mention in their study that handloom industry is perhaps the most important among the hundreds of small scale and cottage arts and crafts that have survived in India. The study 
focused on the awareness level and social demographic profile of the handloom weavers of Jaipur district. The study found that there is an overall low level of awareness among the weavers on various aspects of a cooperative society and government programmes. The researcher suggests various steps to strengthen the productivity of the weavers. Mintu Kundu (2014) said the future prospects and further development of handloom industry is possible and if the industry grows well and if the industry grows well and can solve the present problems of backwardness. Shipra Banarjee (2014) in her study explained about the handloom industry in Northern, Southern, and Central region of Chhattisgarh with reference of the number of weaving cooperative societies operated, number of activities and number of weavers employed. The study revealed that the central region of the Chhattisgarh consists of maximum handloom units and finds that the increasing number of weaving cooperative and active looms resulted in increased number of weavers. The studies referred in the earlier paragraphs confined to either certain regions or some specific issues of handloom industry. None of the studies focused on handloom clusters and measured the impact of the clusters on the socio-economic conditions of the weavers. The present study has been taken up to fill the gap and to contribute for the development of the handloom industry.

\section{Objectives of the Study}

The main objective of the study is to analyze the social conditions of the weavers covered under Integrated Handloom Cluster Development Scheme (IHCDS) of Andhra Pradesh state, India.

\section{Research Methodology and Hypotheses}

For the purpose of the study, the required data has been collected through primary and secondary sources. The secondary data was collected from the Department of Handlooms and Textiles, Government of Andhra Pradesh, APCO, and other related government offices. The data and information was also collected from research reports, journals, publications, websites, and district offices. Further, the secondary data are also collected from the administrative office of the selected clusters. The primary data was collected from weavers working under cluster scheme. The Andhra Pradesh state is selected for the study. Since the weavers are present in all most all the district of Andhra Pradesh in large number, the census study is beyond the capacity of the researcher. Therefore, three districts namely Ananthapur, East Godavari, and Srikakulam are selected based on existence of large number of clusters compared to other districts of Andhra Pradesh. The member weavers of all the 14 clusters form the sample frame. Survey method is used to collect information from weavers. The research instrument was structured questionnaire. Since the size of the population is large, quota sampling method is used to decide sample size. The size of the sample for each district was 150 weavers working under cluster scheme. Thus, the sample size of the three selected districts was 450. Simple random sampling technique is used to select sample units.

The following hypothesis has been formulated for testing:

$\mathrm{H}_{0}$ : There is no significant impact of the IHCDS on the Social conditions of member weavers.

$\mathrm{H}_{\mathrm{A}}$ : There is a significant impact of the IHCDS on the Social conditions of member weavers.

\section{Demographic Profile Of The Respondents}

The study analyzes the demographic profile of the respondents with reference to age, gender, education background, monthly income, and place of residence as shown in table 3 .

\section{Table 3: Demographic Profile of Respondents}

$$
(n=450)
$$

\begin{tabular}{|c|c|c|c|c|}
\hline \multirow[t]{2}{*}{ Factor } & \multicolumn{3}{|c|}{ Districts } & \multirow[t]{2}{*}{ Total } \\
\hline & $\begin{array}{l}\text { Srikak } \\
\text { ulam }\end{array}$ & $\underset{r}{\text { Guntu }}$ & $\begin{array}{l}\text { East } \\
\text { Godava } \\
\text { ri }\end{array}$ & \\
\hline \multicolumn{5}{|c|}{ Age } \\
\hline $\begin{array}{l}30 \& \\
\text { below }\end{array}$ & $\begin{array}{l}8 \\
(1.77)\end{array}$ & $\begin{array}{l}9 \\
(1.99)\end{array}$ & $\begin{array}{l}11 \\
(2.44)\end{array}$ & $\begin{array}{l}28 \\
(6.22)\end{array}$ \\
\hline $31-40$ & $\begin{array}{l}48 \\
(10.66)\end{array}$ & $\begin{array}{l}36 \\
(8.00)\end{array}$ & $\begin{array}{l}33 \\
(7.33)\end{array}$ & $\begin{array}{l}117 \\
(26.00 \\
)\end{array}$ \\
\hline $41-50$ & $\begin{array}{l}48 \\
(10.66)\end{array}$ & $\begin{array}{l}38 \\
(8.44)\end{array}$ & $\begin{array}{l}42 \\
(9.33)\end{array}$ & $\begin{array}{l}128 \\
(28.44 \\
)\end{array}$ \\
\hline $\begin{array}{l}\text { Above } \\
\mathbf{5 0}\end{array}$ & $\begin{array}{l}46 \\
(10.22)\end{array}$ & $\begin{array}{l}67 \\
(14.88 \\
) \\
\end{array}$ & $\begin{array}{l}64 \\
(14.22)\end{array}$ & $\begin{array}{l}177 \\
(39.33 \\
)\end{array}$ \\
\hline \multicolumn{5}{|l|}{ Gender } \\
\hline Male & $\begin{array}{l}101 \\
(22.44)\end{array}$ & $\begin{array}{l}98 \\
(21.77 \\
)\end{array}$ & $\begin{array}{l}121 \\
(26.88)\end{array}$ & $\begin{array}{l}320 \\
(71.11 \\
) \\
\end{array}$ \\
\hline
\end{tabular}


International Journal of Trend in Scientific Research and Development (IJTSRD) ISSN: 2456-6470

\begin{tabular}{|c|c|c|c|c|}
\hline Female & $\begin{array}{l}49 \\
(10.88)\end{array}$ & $\begin{array}{l}52 \\
(11.55 \\
) \\
\end{array}$ & $\begin{array}{l}29 \\
(6.44)\end{array}$ & $\begin{array}{l}130 \\
(28.88 \\
)\end{array}$ \\
\hline \multicolumn{5}{|c|}{ Education } \\
\hline $\begin{array}{l}\text { Illitera } \\
\text { te }\end{array}$ & $\begin{array}{l}121 \\
(26.88)\end{array}$ & $\begin{array}{l}129 \\
(28.66 \\
) \\
\end{array}$ & $\begin{array}{l}127 \\
(28.22)\end{array}$ & $\begin{array}{l}337 \\
(83.88 \\
)\end{array}$ \\
\hline$\overline{\text { SSC }}$ & $\begin{array}{l}22 \\
(4.88)\end{array}$ & $\begin{array}{l}14 \\
(3.11)\end{array}$ & $\begin{array}{l}16 \\
(3.55)\end{array}$ & $\begin{array}{l}52 \\
(11.55 \\
)\end{array}$ \\
\hline $\begin{array}{l}\text { Interm } \\
\text { ediate }\end{array}$ & $\begin{array}{l}5 \\
(1.11) \\
\end{array}$ & $\begin{array}{l}4 \\
(0.88) \\
\end{array}$ & $\begin{array}{l}5 \\
(1.11) \\
\end{array}$ & $\begin{array}{l}14 \\
(3.11)\end{array}$ \\
\hline $\begin{array}{l}\text { Gradu } \\
\text { ation - } \\
\text { tech }\end{array}$ & $\begin{array}{l}1 \\
(0.22)\end{array}$ & $\begin{array}{l}3 \\
(0.66)\end{array}$ & $\begin{array}{l}2 \\
(0.44)\end{array}$ & $\begin{array}{l}6 \\
(1.33)\end{array}$ \\
\hline $\begin{array}{l}\text { Diplom } \\
\text { a }\end{array}$ & $\begin{array}{l}1 \\
(0.22)\end{array}$ & $\begin{array}{l}0 \\
(0.00)\end{array}$ & $\begin{array}{l}0 \\
(0.00) \\
\end{array}$ & $\begin{array}{l}1 \\
(0.22)\end{array}$ \\
\hline
\end{tabular}

\begin{tabular}{|c|c|c|c|c|}
\hline \multicolumn{5}{|c|}{ Place of residence } \\
\hline Rural & $\begin{array}{l}120 \\
(26.66)\end{array}$ & $\begin{array}{l}100 \\
(22.22 \\
)\end{array}$ & $\begin{array}{l}120 \\
(26.66)\end{array}$ & $\begin{array}{l}340 \\
(75.55 \\
)\end{array}$ \\
\hline Urban & $\begin{array}{l}30 \\
(6.66)\end{array}$ & $\begin{array}{l}50 \\
(11.11 \\
)\end{array}$ & $\begin{array}{l}30 \\
(6.66) \\
\end{array}$ & $\begin{array}{l}110 \\
(24.44 \\
\text { ) }\end{array}$ \\
\hline
\end{tabular}

\begin{tabular}{|c|c|c|c|c|}
\hline \multicolumn{2}{|c|}{ Monthly income } & \multicolumn{3}{|c|}{ 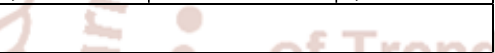 } \\
\hline $\begin{array}{l}\text { Rs. } \\
5000 \\
\text { and } \\
\text { below }\end{array}$ & $\begin{array}{l}25 \\
(5.55)\end{array}$ & $\begin{array}{l}15 \\
(3.33)\end{array}$ & $\begin{array}{l}48 \\
(10.66)\end{array}$ & $\begin{array}{l}88 \\
(19.55 \\
)\end{array}$ \\
\hline $\begin{array}{l}\text { Rs } \\
5000 \quad- \\
10000\end{array}$ & $\begin{array}{l}117 \\
(26.00)\end{array}$ & $\begin{array}{l}84 \\
(18.66 \\
) \\
\end{array}$ & $\begin{array}{l}56 \\
(12.44)\end{array}$ & $\begin{array}{l}257 \\
(57.11= \\
)\end{array}$ \\
\hline $\begin{array}{l}\text { Rs } \\
10001- \\
15000\end{array}$ & $\begin{array}{l}14 \\
(3.11)\end{array}$ & $\begin{array}{l}16 \\
(3.55)\end{array}$ & $\begin{array}{l}18 \\
(4.00)\end{array}$ & $\begin{array}{l}48 \\
(10.66\end{array}$ \\
\hline $\begin{array}{l}\text { Above } \\
\text { Rs.200 } \\
00\end{array}$ & $\begin{array}{l}4 \\
(0.88)\end{array}$ & $\begin{array}{l}8 \\
(1.77)\end{array}$ & $\begin{array}{l}45 \\
(10.00)\end{array}$ & $\begin{array}{l}57 \\
(12.66\end{array}$ \\
\hline
\end{tabular}

Source: Primary Data

this profession. The gender wise distribution of respondents reveals that out of the total, 71.11 per cent of the respondents are males and about 29 percent are females. The female respondents are relatively more in East Godavari and Ananthapur districts. The female respondents are less in number in Srikakulam district. The district wise educational background of the respondents shows that about 84 per cent of the respondents are illiterate persons. There are 11.55 per cent of the respondents who studied SSC. The respondents who completed intermediate education were 3.11 per cent. Graduates are 6 in number representing 1.33 per cent of the total, while 1 respondent completed diploma course.

The analysis regarding the place of residence shows that 76 per cent of the respondents belong to rural areas and while 24.44 per cent of the respondents carry out the profession in urban areas. The monthly family income of the respondents varied between Rs. $5,000 \&$ below and above Rs.20, 000. The monthly family income of 10.66 per cent of the respondents is in range of Rs. 10,000 to Rs. 15,000 and 57.11 per cent of the respondents varied between Rs.5,000 and Rs 10000. There are 12.66 per cent of the respondents whose monthly income is more than Rs.20,000 while the monthly family income of 19.55 of the respondents was Rs.5,000 and below.

\section{Data Analysis}

The study attempts to know the impact of Integrated Handloom Cluster Development Scheme (IHCDS) on Social conditions of weavers using mean and percentage score values as shown in table-4. As per the findings of the study the null hypothesis of social conditions is rejected. The impact of social conditions is assessed based on the opinion of the respondents on the six statements expressed on five point scale ranking between sternly agree to strongly disagree.

The table 1 reveals the demographic profile of the respondents. The age of the respondents varied between below 30 years and above 50 years. The data reveals that the largest groups of the respondents are in the age group of above 50 years (39.33 percent). Out of the total, 28.44 per cent of the respondents are in 41-50 years age group and 26 per cent of the respondents belong to 31-40 years age group. The respondents who are in the age group of 30 years and below are very less in number representing 6.22 per cent. It can be inferred from the data that the handloom sector is unable to attract youngsters in to 
International Journal of Trend in Scientific Research and Development (IJTSRD) ISSN: 2456-6470

Table-4. Impact of IHCDS on Social Conditions of Weavers $(n=450)$

\begin{tabular}{|l|l|l|}
\hline Social Conditions & Mean & $\begin{array}{l}\text { Percentage } \\
\text { Score }\end{array}$ \\
\hline $\begin{array}{l}\text { Member ship in cluster } \\
\text { enhanced social status } \\
\text { of the weavers }\end{array}$ & 1.63 & 15.83 \\
\hline $\begin{array}{l}\text { All the family members } \\
\text { find full time work } \\
\text { under the scheme }\end{array}$ & 1.56 & 14.06 \\
\hline $\begin{array}{l}\text { Taken care of children } \\
\text { education }\end{array}$ & 1.70 & 16.83 \\
\hline $\begin{array}{l}\text { The quality of family } \\
\text { life enhanced }\end{array}$ & 1.69 & 17.28 \\
\hline $\begin{array}{l}\text { Our future is secured } \\
\text { under the scheme }\end{array}$ & 1.65 & 16.39 \\
\hline $\begin{array}{l}\text { Increased harmony in } \\
\text { social relations }\end{array}$ & 3.06 & 51.50 \\
\hline Average mean & 1.88 & 21.98 \\
\hline
\end{tabular}

Source: Primary data

It can be observed from the table- 4 that the mean score of the six statements varied between 1.56 and 3.06. The opinion is slightly positive on only one statement i.e., increased harmony in social relations. The five statements got a mean value of less than two each. The overall mean value of the opinion of respondents on the impact of Integrated Handloom Cluster Development Scheme of social conditions of weavers is 1.88 . It can be inferred from the table that in the opinion of respondents there is no significant impact of Integrated Handloom Cluster Development Scheme on social conditions of member weavers.

Table-5. Health Problems due to Profession

\begin{tabular}{|l|l|l|l|l|}
\hline \multirow{2}{*}{ Particulars } & \multicolumn{2}{|l|}{ District } & \multirow{2}{*}{ Total } \\
\cline { 2 - 4 } & $\begin{array}{l}\text { Ananth } \\
\text { apur }\end{array}$ & $\begin{array}{l}\text { East } \\
\text { Godavari }\end{array}$ & $\begin{array}{l}\text { Srikak } \\
\text { ulam }\end{array}$ & \\
\hline Yes & 79 & 72 & 79 & $\mathbf{2 3 0}$ \\
& $(17.55)$ & $(16.00)$ & $(17.55)$ & $\mathbf{( 5 1 . 1 1 )}$ \\
\hline No & 71 & 78 & 71 & $\mathbf{2 2 0}$ \\
& $(15.77)$ & $(17.33)$ & $(15.77)$ & $\mathbf{( 4 8 . 8 8 )}$ \\
\hline Total & 150 & 150 & 150 & $\mathbf{4 5 0}$ \\
& $(33.33)$ & $(33.33)$ & $(33.33)$ & $\mathbf{( 1 0 0 . 0 0 )}$ \\
\hline
\end{tabular}

Chi-square: 0.872, P-Value: 0.647, Not Significant

Source: Primary data;

One of the major problems faced by weaving community is health hazards due to the nature of activities to perform in handloom cloth production process. When enquired, more than 50 per cent of the respondents revealed that they are facing health problems due to their profession (Table-5). The result of Chi- Square test indicates that there is no relation between Health Problems and district as the value of Chi- square 0.872 and P-value is 0.647 .

\section{Results and Discussions}

Multiple linear Regressions (MLR) analysis was carried out to study and establish the relationship between the demographic factors (district, gender, age, education and monthly income) of respondents and impact on social conditions on the member weavers as shown in table- 6 .

Table-6. Regression Analysis:

Social Conditions versus District, Gender, Age, Education and Income

\begin{tabular}{|l|l|l|l|l|l|}
\hline Source & DF & Adj. SS & Adj. MS & $\begin{array}{l}\text { F- } \\
\text { Value }\end{array}$ & $\begin{array}{l}\text { P- } \\
\text { Value }\end{array}$ \\
\hline Regression & 13 & 1.482 & 0.113998 & 1.33 & 0.189 \\
\hline District & 2 & 0.7178 & 0.358924 & 4.2 & 0.016 \\
\hline Gender & 1 & 0.0015 & 0.001544 & 0.02 & 0.893 \\
\hline Age & 3 & 0.3314 & 0.11047 & 1.29 & 0.276 \\
\hline Education & 4 & 0.2789 & 0.069725 & 0.82 & 0.515 \\
\hline Income & 3 & 0.2375 & 0.079164 & 0.93 & 0.428 \\
\hline Error & 436 & 37.2356 & 0.085403 & & \\
\hline $\begin{array}{l}\text { Lack-of- } \\
\text { Fit }\end{array}$ & 96 & 8.8295 & 0.091974 & 1.1 & 0.267 \\
\hline $\begin{array}{l}\text { Pure } \\
\text { Error }\end{array}$ & 340 & 28.4061 & 0.083547 & & \\
\hline Total 170 & 449 & 38.7175 & & & \\
\hline R-sq 3.83 & & & & \\
\hline
\end{tabular}

The R-Square value shows that regression model explains 3.83 per cent of the variance in strength, indicating that the model does not fits the data fairly well. The R-square value considers the regression equation in the model and examines the strength of the independent variables in predicting the dependent variable. It exemplifies that there is no significant linear relationship between the demographic factors extracted above and their probability of association with various statements related to Impact of social conditions of handloom cluster weavers. Only one variable (District) out of five contributed significantly to the equation at 5 per cent level i.e., the analysis of variance table indicates that the relationship between district and economic conditions is significant $(\mathrm{P}=$ 0.026) as shown in table-7. 
International Journal of Trend in Scientific Research and Development (IJTSRD) ISSN: 2456-6470

Table 7: ANOVA's - Impact of clusters on Social Conditions of the Respondents

\begin{tabular}{|l|l|l|l|l|l|}
\hline District & N & Mean & SD & $\begin{array}{l}\text { F- } \\
\text { Value }\end{array}$ & $\begin{array}{l}\text { P- } \\
\text { Value }\end{array}$ \\
\cline { 1 - 4 } Ananthapur & 150 & 1.93 & 0.3024 & 3.69 & 0.026 \\
\cline { 1 - 3 } \\
$\begin{array}{l}\text { Godavari } \\
\text { Srikakulam }\end{array}$ & 150 & 1.8667 & 0.2744 & & \\
\cline { 1 - 3 } & 1.8411 & 0.2981 & & \\
\hline
\end{tabular}

Thus, the finding of the study rejects the hypothesis. So, there is no significant impact of the IHCDS on the Social conditions of member weavers.

\section{Conclusion}

Handloom sector is highly labor intensive industry with low capital investment. It is also a low energy sector with no adverse impact on the environment as weaving is a totally pollution free activity. The strength of handloom lies in the introducing innovative designs, which cannot be replicated by the power loom sector. The impact of social conditions is assessed based on the opinion of the respondents on the following six statements expressed on five point scale ranking between sternly agree to strongly disagree. Membership in cluster enhanced social status of the weavers, all the family members find full time work under the scheme, taken care of children education, the quality of family life enhanced, future is secured under the scheme, and increased harmony in social relations.

The mean score of the six statements varied between 1.56 and 3.06 . The opinion is slightly positive on only one statement i.e., increased harmony in social relations. The five statements got a mean value of less than two each. The overall mean value of the opinion of respondents on the impact of Integrated Handloom Cluster Development Scheme of social conditions of weavers is 1.88 . It can be inferred from the study that in the opinion of respondents there is no significant impact of Integrated Handloom Cluster Development Scheme on social conditions of member weavers.

\section{References}

1) Ahmad, Fayaz, Nengroo A. Hussain, (2013), “An analysis of Handloom Sector of Jammu and Kashmir; A Case Study of District Budgam”, International Journal of Management and Business Studies, Vol. 3(1), pp. 106.
2) Anant Kamath and Robin Cowan, (2012), "Community Cohesion and Inherited Networks, A Network Study of two Handloom Clusters in Kerala, India", Unu-Merit Working Papers, Maastricht Economic and Social Research Institute on Innovation and Technology, November, pp.1-30.

3) Arif Anjum and Thakor. D.V., (2011), "An Analytical Study of the Functioning and the Problems of the Power loom Industry in Maharashtra with Special Reference to Malegaon Dist. Nasik" , International Journal of Trade, Economics And Finance, Vol. 2, No. 3, June, pp.194-198.

4) Bharathan, K., (1988), "The Handloom Industry in Tamil Nadu: A Study of Organizational Structure", University of Madras.

5) Gurumoorthy T.R. and Rengachary R.T., (2002), Problems of Small Scale Industries, Concept Publishing House, New Delhi,vol.1, pp168-178.

6) Lakshmi Narasaiah M. and Krishna Ch.T., (1999), "Crisis of Handloom Industry." New Delhi: Discovery Publishing House.

7) Laxmi Narasaiah M, (2004), "Economics of Handloom Industry", Sonali Publications, New Delhi.

8) Mahaptro P.C. (1986), "Economics of Cotton Handloom Industry in India," Asia Publishing House, New Delhi.

9) Mahendra et al. (2008) "Economics of Handloom Weaving:a Field Study in Andhra Pradesh", Economic and Political Weekly, May 24, pp-4357.

10) Merima ali, (2010), "Clustering as an Organizational Response to Capital Market inefficiency", International Food Policy Research institute, December, pp.1-26.

11) Mintu Kundu, (2014), “Cotton Handloom Industry Problems and Prospects of Development", A case study of Alipurduea block-ii, vol. 3, Issue.1, January, pp. 83-85.

12) Mukund, K and B. Syamasundari, (2001), "Traditional Industry in the New Market Economy-The Cotton Handlooms of Andhra Pradesh", New Delhi: Sage Publications.

13) Premsundar, B and Kannan J, (2013), "Women in Handloom Industry, Problems and Prospects", 
Epra International Journal of Economic and Business Review, Vol.1, Issue- 1, December, pp.32-38.

14) Rama Mohan Rao. K. (1990), "Development of Handloom Industry", Discovery Publishing House, New Delhi.

15) Ramachandrappa N.T., (2009), "Insight of Gadag Handloom Cluster, Published On Fibre2fashion.com, Wednesday, October 21, pp.1.

16) Rao S.J. (1979), "Handloom Industry Yarn Policy", Cheneta, Vol.2, No.2, September 15th.

17) Rubyjain aad Rachana Goswami, (2013), "Awareness a Determinate of Socio Demography of Handloom Weavers Associated With Rajasthan Rajya Bunker Sahkari Sangh of Jaipur District", Indian Streams Research Journal Vol.3, Issue.5, June, pp.1-10.

18) Sabeenian R S, Paramasivam $M E$ and Dinesh $P$ M., (2012), "Fabric Defect Detection In handlooms Cottage Silk Industries Using Image Processing Techniques", International Journal of Computer Applications, Vol.58, November, pp.21-29.

19) Savita Modak, (2006), "Weaving Customers' Dreams". Economic and Political Weekly, Vol. 41, No.31, August, pp-3367-3368.

20) Shipra banarjee, (2014), "A Comparative Study of Handloom Industries in Chhattisgarh", International Journal of Innovative Research in Technology and Science, Vol.2, May, pp.10-14.

21) Tasneem Shazli and Abdul Munir, (2014), "Female Work Participation in Handloom Industry-A Case Study of Mubarakpur Town, Azamgarh District, U.P.”, Journal of Education and Social Policy Vol. 1, No. 1, June, pp. 76-83.

22) Tawheed yousuf ishfaq khan, Tawseef yousuf and Tariqahmad raja, (2013), "Socio-Economic Profile of Silk Weavers, A Micro-Level Study of Srinagar City", European Academic Research, Vol.1, No. 3, pp. 319-331. 